\title{
MIKA OJAKANGAS
}

\section{I B ERA L IS M I, DEM O KRATIA JA TOTAALINEN VALTIO}

\author{
Carl Schmitt \\ REPRESENTAATION JA IDENTITEETTIN VÄLISSÄ
}

Yleinen keskustelu osoittaa, että vielä nykyäänkin - tai ehkä etenkin nykyään - demokratia sekoitetaan helposti sellaisiin periaatteisiin ja institutionaalisiin järjestelyihin, joiden tarkoituksena on pikemminkin $\mathrm{ra}$ joittaa kansan (demos) valtana (kratos) ymmärrettyä demokratiaa kuin toteuttaa sitä. Kun puhutaan vallan kolmijaosta, vedotaan sen demokraattisuuteen, vaikka kyse on institutionalisoidusta yrityksestä ehkäistä kansan tahdon välitöntä ilmaisemista ja pyrkimyksestä asettaa turvallinen järkevyysperiaate paljasta valtaa vastaan. Kun puhutaan oikeusvaltiosta ja laillisuusperiaatteesta, korostetaan niin ikään näiden järjestelyiden demokraattista luonnetta, vaikka jälleen kyse on vain liberaalista pyrkimyksestä vastustaa niin sanottua mielivaltaa - oli tuon mielivallan subjektina sitten kuningas tai kansa. Tai aina kun mainitaan sana vaalit, halutaan painottaa järjestelmän demokraattisuutta, vaikka salainen äänestäminen viittaa jälleen pikemminkin liberaaliin yksityisyyden suojaan kuin demokraattiseen julkisuusperiaatteeseen. Samassa yhteydessä korostetaan kansanedustuslaitoksen demokraattista luonnetta, vaikka vapaalla mandaatilla toimiva kansanedustaja, jota lakien ohella sitoo vain to- tuus ja oikeus, viittaa yhtä lailla aristokraattiseen periaatteeseen. Niin ikään ne, jotka kritisoivat puoluekuria, haluavat tehdä eduskunnasta entistä demokraattisemman, vaikka jäsenistönsä kautta puolueet ovat usein suoremmassa suhteessa kansan todelliseen tahtoon - ihmisten materiaalisiin intresseihin - kuin vapaalla mandaatilla toimivat yksittäiset kansanedustajat konsanaan. Tämä kaikki, joka sellaisenaan on itsestään selvää ja banaalia, ei tietenkään tarkoita, että nämä periaatteelliset ja institutionaaliset järjestelyt olisivat jossain mielessä huonoja ja järjettömiä. Päinvastoin ne ovat monessa mielessä hyviä ja järjellisiä. Se tarkoittaa vain, että on lakattava puhumasta yksinomaan demokratiasta silloin, kun kyse on aivan jostain muusta kuin demokraattisista periaatteista. Tämä kuitenkin edellyttää tietoa periaatteista ja aattellisista perustoista.

Yksi parhaimmista poliittisten periaatteiden ja viimekätisten aatteellisten perustojen esittäjistä on tällä vuosisadalla ehdottomasti ollut saksalainen valtiosääntöjuristi ja valtio-oppinut Carl Schmitt (1888-1985). Schmitt oli katolinen kulttuurikonservatiivi, jonka rakkaus auktoriteettia ja valtiota kohtaan saattaa näinä valtionvastaisina aikoina 
olla monen mielestä vain osoitus hänen luonteensa kieroutuneisuudesta. Niin ikään

hänen kriittinen suhtautumisensa yksilöä, etiikkaa ja taloutta korostavaa liberalismia ja etenkin keskustelun kautta totuuteen pyrkivää parlamentarismia kohtaan voi aiheuttaa moraalista paniikkia niiden keskuudessa, joille yksilö on kaiken alku ja loppu, etiikka inhimillisestä näkökulmasta olemassaolon kauneinta taidetta ja talous rauhanomaista vaihtoa - tai joille loputon keskustelu edustaa ihmiskunnan kehityksen huippua. Schmittin liberalismin ja parlamentarismin kritiikki oli monta kertaa kuitenkin vain välineellistä, sillä hänen todellisia vihollisiaan olivat yhtäältä jakobinismi ja bolsevismi, joiden destruktiivisuutta ei liberaalein periaattein ja parlamentaarisin järjestelyin hänen mukaansa kyetä rajoittamaan, sekä toisaalta anonyymi tekninen maailmanhallinta, johon liberalismin ideologia ja päättämättömyyteen kangistunut parlamentaarinen käytäntö tosiasiassa vähä vähältä johtaa. Jakobiinien kaaoksen voi asettaa järjestykseen ja "nihilistiselle sentralisaatiolle" voi antaa mielen vain uusi Leviathan - kansallisen järjestyksen asettava ja maailman moneuden ehtona oleva representatiivinen auktoriteetti. ${ }^{1}$

\section{VAPAUDEN PAATOS}

Schmittin mukaan kaikkia valtioteorioita ja poliittisia aatteita voidaan testata niiden omaksuman antropologian mukaan ja näin luokitella ne sen mukaan, edellyttävätkö ne tietoisesti tai tiedostamattaan ihmisen, joka on luonnoltaan paha tai hyvä. Yksikään teoria tai aate, joka pitää ihmistä hyvänä, ei hänen mukaansa ole aidosti poliittinen: "Kaikki aidot poliittiset teoriat edellyttävät, että ihminen on 'paha', toisin sanoen, ei missään mielessä ongelmaton vaan 'vaarallinen' ja dynaaminen olento." Schmittille poliittinen edellyttää - ei vain vihollisen reaalista mahdollisuutta ${ }^{3}$ vaan hierarkkista valtasuhdetta. Ilman valtaa ei ole poliittista ja ilman ihmisen pahuutta ei ole valtaa. Valtaa on mahdotonta legitimoi- da muuten kuin ihmisen mahdollisen vaarallisuuden ja vallan tuoman turvallisuuden avulla: "Yksinomaan inhimillisestä näkökulmasta suojelemisen ja tottelemisen suhde on ainoa selitys vallan olemassaololle." ${ }^{4}$ Sen sijaan, jos ihminen osoittautuu kaikin puolin hyväksi tai kiltiksi ja kesyisäksi olennoksi eikä näin ollen tarvitse käskemistä tai suojelua, ei vallallakaan ole mitään olemassaolon oikeutusta. Schmittille vallan ( $k r a-$ tos) häviäminen merkitsee poliittisen katoamista. Tämän takia anarkismilla, jonka lähtökohtana on kaiken vallan absoluuttinen pahuus ihmisen absoluuttista hyvyyttä vastaan, ei Schmittin mukaan voi olla omaa poliittista teoriaa. Saman tuomion saa hänen käsittelyssään liberalismi.

On totta, että kaikki liberalismin teoreetikot eivät ole pitäneet ihmistä anarkistien tapaan hyvänä, mutta Schmittin mukaan liberalismin doktriini, jossa individualistinen yhteiskunta määrää oman järjestyksensä ja valtio alistetaan tämän järjestyksen palvelijaksi, viittaa ongelmattomaan ihmiskuvaan. Klassisesti tuon ajatuksen on muotoillut Thomas Paine, jonka mukaan yhteiskunta tyydyttää tarpeemme ja valtio on vain "välttämätön paha". ${ }^{5}$ Niin ikään Schmitt myöntää, että liberalismi ei ole koskaan ollut poliittisesti radikaalia anarkismin tapaan, mutta hänen mukaansa on itsestään selvää, että liberalismin suorittamilla neutralisaatiolla, depolitisaatiolla ja vapauden julistuksilla on poliittinen merkitys. Ne on suunnattu poleemisesti valtiota ja sen poliittista valtaa vastaan yksilöllisen vapauden, yksityisomaisuuden ja taloudellisen kilpailun puolesta: "Kaikki liberaali paatos kääntyy valtaa [Gewalt] ja vapauden puutetta vastaan. Jokaista loukkausta, jokaista uhkaa yksilölliselle vapaudelle ja yksityisomaisuudelle ja vapaalle kilpailulle kutsutaan 'väkivallaksi' [Gewalt] ja on eo ipso jotakin pahaa." ${ }^{6}$ Schmittin mukaan politiikan - poliittisessakaan - negaatiossa ei kuitenkaan voi olla kyse vielä poliittisesta teoriasta tai poliittisesta ideasta. Voi olla, että liberalismi ei ole radikaalilla tavalla kieltänyt valtiota, mutta Schmittin mukaan se ei ole 
myöskään esittänyt positiivista teoriaa valtiosta tai politiikasta eikä kyennyt näkemään, miten kehittää valtiota, vaan on yrittänyt ainoastaan sitoa poliittisen eettiseen ja alistaa ne taloudelle. ${ }^{7}$

Tämä sitominen ja alistaminen on ymmärrettävää, jos Walter Rathenaun tavoin uskoo, että kohtalomme ei enää ole politiikka vaan talous. Schmitt ei usko Rathenauta. Politiikka on edelleen kohtalomme, mutta taloudesta on tullut poliittista. Sitä paitsi on virheellistä uskoa, että taloudelliseen kanssakäymiseen tai vaihtoon perustuva yhteiskunta on "olennaisesti ei-sotaisa”, kuten Joseph Schumpeter ehdottaa, sillä tosiasiassa ei-sotaisaa on vain liberaalin ideologian terminologia. Käytäntö viittaa vähemmän rauhanomaisiin ratkaisuihin. Sota ehkä tuomitaan, mutta pakotteet, rankaisutoimenpiteet, rauhaanpakottamiset, sopimusten suojelu, kansainvälinen poliisi ja rauhan säilyttämistoimenpiteet jäävät jäljelle. Vaihto ei toisin sanoen sulje pois pahimmankaan hyväksikäytön ja riiston mahdollisuutta. Kun riistetyt tässä tilanteessa yrittävät puolustaa itseään, on selvää, että he eivät voi tehdä sitä taloudellisin keinoin, mutta taloudellisen vallan haltija pitää jokaista yritystä muuttaa valta-asetelmaa ulkotaloudellisin keinoin väkivaltana ja rikoksena. ${ }^{8}$ Taloudellinen valta on näin ollen yhtä pakottavaa kuin poliittinen, mutta toisin kuin poliittinen valta, joka Schmittin mukaan perustuu vastuullisuuteen ja näkyvyyteen, taloudellinen valta pyrkii kätkeytymään ja kiertämään kysymyksen vastuusta.

\section{TOTAALINEN VALTIO}

Schmittin mukaan 1900-luvun alun reaktio 1800-luvun liberalistiselle kaikkien keskeisten aluiden neutralisaatiolle ja depolitisaatiolle oli niiden politisoituminen ja valtiollistuminen. 1800-luvun liberalismin neutraali valtio sai näin vastaansa 1900-luvun totaalisen valtion. Schmittille totaalinen valtio on se, jonka puitteissa ei ole olemassa mitään, mikä ei jollain tavoin olisi suhteessa valtioon: "Se puuttuu kaikkiin mahdolli- siin asioihin inhimillisen olemassaolon kaikilla alueilla." Totaalisessa valtiossa ei ole enää yhtään aluetta, "jota valtion pitäisi pitää ehdottoman neutraalina, väliintulemattomuuden merkityksessä". ${ }^{10}$ Kyse ei ole 1700-luvun absoluuttisesta valtiosta, joka seisoo yhteiskunnan yläpuolella vakaana ja erillisenä voimana, eikä edes Hegelin ja hänen seuraajiensa hahmottelemasta universaalista valtiosta, joka asettuu yhteiskunnan yläpuolelle moraalisen ylivoimaisuutensa takia. Kyse on 1800-luvun - yhteiskunnasta vetäytyvän - neutraalin valtion symmetrisestä vastakohdasta, 1900-luvun demokraattisesta valtiosta, jossa valtio (Staat) ja yhteiskunta (Gesellschaft) sekoittuvat jäännöksettä toinen toisiinsa - "kuten täytyy tapahtua välttämättä jokaisessa demokraattisesti organisoidussa yhdyskunnassa [Gemeinwesen]". ${ }^{11}$

Toisin sanoen kun liberalismi uskoi eristävänsä talouden ja lopulta koko yhteiskunnan poliittisen alueelta, asettavat 1900-luvun demokraattinen aate tavoitteekseen järjestyksen, jossa mikään ei välttämättä kuulu poliittisen ulkopuolelle. Koko yhteiskunta, kaikki se mikä aiemmin samastettiin julkisen ja poliittisen ulkopuolelle kuuluvaan yksityiseen tai taloudelliseen - jotka viime kädessä viittaavat samaan oikonomian käsitteeseen - politisoituu. Schmittin mukaan tämä politisoituminen on kuitenkin vain looginen päätepiste demokratian perustana olevalle substantiaalisen tasaarvon ideologialle. Yhteiskunnan ja valtion identiteetti vastaa demokratian perustana olevaa hallittujen ja hallitsevien identiteettiä ja tämän identtisyyden pohjalta nousee totaalinen valtio.

Sitä, että Schmitt puhuu totaalisesta valtiosta, on pidetty osoituksena hänen taipumuksestaan totalitaristisiin ratkaisuihin, mutta tosiasiassa kyse on vain konkreettista todellisuutta vastaavan käsitteen muotoilusta. Totaalinen valtio ei ole utopia tulevasta valtiosta vaan olemassa olevaa - 1900luvun alun eurooppalaista - valtiota vastaava muotoilu. ${ }^{12}$ Ei edes liberalismi pysy $1900-$ luvulla uskollisena 1800-luvun periaatteil- 
leen vaan solmii käytännöllisen liiton totaalisen valtion kanssa. Tämä on liberalismille välttämätöntä, sillä säilyäkseen sen on liittouduttava niiden voimakkaiden demokraattisten tendenssien kanssa, jotka hallitsevat koko moderniteetin poliittista ajattelua. ${ }^{13}$ Liberalistinen totaalinen valtio on Schmittin mukaan kuitenkin vain toinen - kvantitativinen - totaalisen valtion tyypeistä. Kvantitatiivinen totaalinen valtio on totaalinen heikkoutensa takia. Pyrkiessään vastaamaan kaikkiin yhteiskuntaelämän vaatimuksiin, se joutuu välttämättä tunkeutumaan - ei vain talouden vaan - inhimillisen olemassaolon kaikille alueille. ${ }^{14}$

Tie liberalistisesta ajattelusta totaaliseen valtioon on paradoksaalinen. Liberalismi vastustaa valtiota puhumalla sen autoritaarisesta ja despoottisesta luonteesta ja vaatii valtion yhteiskunnallistamista, mutta valtion yhteiskunnallistuminen voi tapahtua vain, jos yhteiskunta samalla valtiollistetaan. Tämä valtio ei kuitenkaan ole enää perinteisen liberalismin lakiasäätävä valtio (Gesetzgebungsstaat) - keskiajan lainkäyttövaltiosta (Jurisdiktionsstaat) tai 1600-luvun hallitusvaltiosta (Regierungsstaat) puhumattakaan - vaan, kuten Schmitt teoksessaan Legalität und Legitimität (1932) korostaa, 1900-luvun hallintovaltio (Verwaltungsstaat). Jos lainkäyttövaltiossa hallitsevat juristit ja hallitusvaltiossa suvereeni persoona, hallitsee lakiasäätävässä valtiossa pelkkä normi. Hallintovaltiossa jopa normi on asetettu suvereenina syrjään, sillä se hallitsee tekniseen motiiviin - ennen kaikkea taloudelliseen hyötynäkökulmaan - perustuvien toimenpiteiden (Massnahme) avulla. Se korvaa lailliset normit asetuksilla, määräyksillä, kiertokirjeillä ja direktiiveillä. ${ }^{15}$ Se ei aseta periaatteita - se ei implikoi mitään representaatiota - vaan se pyrkii ratkaisemaan ongelmat välittömästi asioiden itsensä tasolla. Schmittin mukaan modernin valtion - sikäli kuin sen ensisijaisena huolen kohteena on talous - täytyy itse asiassa kohtalonomaisesti muuttua hallintovaltioksi. ${ }^{16}$

Kvantitatiivinen totaalinen valtio - liberaali hallintovaltio - on totaalinen heikkoutensa takia, mutta sitä vastaan asettuu kvalitativinen totaalinen valtio. Tämä valtio on totaalinen voimansa kautta. ${ }^{17}$ Se ei pyri vastaamaan yhteiskuntaelämän jokaiseen vaatimukseen, mikä Schmittin mukaan johtaa valtiollisen voiman samastumiseen yhteiskunnallisten voimien - puolueiden ja korporaatioiden - keskinäisen kompromissin voimaan ja lopulta valtion auktoriteetin luhistumiseen. Pikemminkin se kohoaa 1600-luvun hallitusvaltion tavoin - yhteiskunnan yläpuolelle ottaen itselleen politiikan monopolin. Yhtäältä tämä mahdollistaa ystävän erottamisen vihollisesta, toisaalta poliittisen erottamisen epäpoliittisesta. Tällainen depolitisointi ei kuitenkaan merkitse valtion heikkoutta, sillä Schmittin mukaan "ainoastaan vahva valtio voi vetäytyä ei-valtiollisista asioista”. ${ }^{18}$ Tässä vetäytymisessä ei nimittäin ole kyse politiikanteosta luopumisesta. Nykyoloissa - Schmitt kirjoittaa vuonna 1933 - depolitisoiminen on päinvastoin erityisen intensiivisellä tavalla poliittinen teko. ${ }^{19}$ Jos kvantitatiinen totaalinen valtio ei erota mitään aluetta, joka on vapaa valtion väliintulosta, johtuu tämä pelkästään siitä, että se ei kykene "erottelemaan mitään". ${ }^{20}$ Kun erottelukyky on poliittinen kyky par excellence, on kvantitatiivinen totaalinen valtio - kaikesta totaalisuudestaan huolimatta - näin ollen epäautenttinen, ja kvalitatiivinen totaalinen valtio puolestaan autenttinen totaalinen valtio. Itse asiassa kvantitatiivinen totaalinen valtio ei ole valtio lainkaan, sillä Schmittille jokainen "todellinen valtio" on aina kyennyt erottamaan ystävän vihollisesta. ${ }^{21}$

Schmittin mukaan fasistinen Italia on kvalitatiivinen totaalinen valtio. ${ }^{22}$ Se, että totaalinen valtio nousee hallittujen ja hallitsijoiden identiteetin pohjalta, ei Schmittin mukaan ole millään tavalla ristiriidassa tämän kanssa. Schmittille se, että fasismi luopuu vaaleista ja halveksii kaikkea elezionismoa, ei ole antidemokraattista vaan antiliberaalia. Itse asiassa Schmitt pitää fasismia tietyssä mielessä jopa demokraattisempana kuin vallitsevaa liberaalia käytäntöä, joka poistaa yhdentyneenä ymmärretyn kansan (Volk) julkisen (Öffentlichkeit) alu- 
eelta - tehden siitä korkeintaan kulttuurisesti kiinnostuneen yleisön (Publicum) - ja redusoi poliittisen tahdonmuodostuksen yksityishenkilöiden salaisesti antamien äänten yhteenlaskuksi ja näin "kontrolloimattoman massan pyrintöjen ja kaunahengen teoksi”. ${ }^{23}$ Toisaalta Schmitt toteaa, että demokraattisen valtion ainoa yleispätevä oikeuttamisen tapa on huutoäänestys (Akklamation): "Kansan tahdon suoran ilmenemismuodon luonnollinen muoto on yhteen kokoontuneen väkijoukon hyväksyntää tai hylkäämistä osoittava huuto." ${ }^{24}$ Se on alkuperäinen demokraattinen periaate, joka nykyään ilmenee julkisen mielipiteen (öffentliche Meinung) muodossa. ${ }^{25}$ Tässä mielessä fasistinen valtio ei varmaankaan täytä demokratian - demokraattisen legitimiteetin - kaikkia ehtoja, mutta Schmittin mukaan sen ehdot täyttyvät yhtä vähän niissä yhteiskunnissa, jotka yrittävät sovittaa liberalistisia periaatteita demokraattisiin periaatteisiin. Hänen mukaansa tämä sekoittuminen on vain johtanut - kuten hän teoksessaan Die Geistesgeschichtliche Lage des heutigen Parlamentarismus (1924) kirjoittaa - moderniin massademokratiaan ja ajanut sen perustana olevan parlamentarismin kriisiin.

\section{PARLAMENTARISMI JA DEMOKRATIA}

Schmittin mukaan parlamentarismin olemus on avoimuudessa ja keskustelussa. Avoin keskustelu ei tarkoita vain neuvotteluita, sillä jopa tyrannit neuvottelevat. Avoin keskustelu merkitsee mielipiteiden vaihtoa, jonka tarkoituksena on argumentaation avulla suostutella vastapuolta omaksumaan oikea käsitys totuudesta ja oikeudenmukaisuudesta sekä antaa vastapuolen vuorostaan olla suostuttelijana. Parlamentarismissa lakien oletetaan syntyvän, kuten Edmund Burke klassisesti ehdottaa, mielipiteiden konfliktin seurauksena eikä etujen taistelussa. Tämän konfliktin - argumenttien vastakkainasettelun - premissinä ovat halukkuus tulla suostutelluksi, itsenäisyys suhteessa puolueisiin sekä vapaus itsekkäiden intressien kahleista.
Schmittin mukaan modernin massademokratian myötä näistä parlamentarismin perusteista ja samalla koko argumentatiivisen julkisen keskustelun ajatuksesta on tullut vain tyhjää formalismia: "Parlamenttilain monet nykyiset normit, ennen kaikkea märäräkset, jotka koskevat edustajien riippumattomuutta ja istuntojen avoimuutta, ovat seurauksiltaan kuten ylimääräinen koristelu, hyödyttömiä ja jopa hämmentäviä, ikään kuin joku olisi maalannut punaisia liekkejä uudenaikaiseen keskuslämmitysjärjestelmän patteriin antaakseen kuvan leimuavasta tulesta." ${ }^{26}$ Puolueet, jotka tosiasiassa hallitsevat, eivät kohtaa toisiaan mielipiteiden vaihdon avoimella näyttämöllä vaan sosiaalisina tai taloudellisina valtaryhmittyminä, jotka tekevät laskelmia ja kompromisseja yksistään tältä pohjalta. Massat ne vuorostaan voittavat puolelleen modernin propagandakoneiston avulla, jonka tehokkuus perustuu sen kykyyn vedota välittömiin intresseihin ja intohimoihin. Todelliselle keskustelulle ominainen argumentaatio katoaa ja sen paikalle ilmaantuu puolueneuvotteluiden tietoinen etujen sovittelu ja vallan keskinäinen jakaminen. Toisaalta ilmaantuu massoille suunnattu argumentoimaton iskulause tai "symboli". ${ }^{27}$

Schmittin mukaan parlamentti on kuin jättisuuri odotussali näkymättömien hallitsijoiden toimistojen ja komiteoiden edessä. $\mathrm{Ne}$, jotka edelleen viittaavat Benthamiin, jonka mukaan "parlamentissa aatteet kohtaavat ja aatteiden kohtaaminen iskee kipinöitä ja johtaa selvyyteen", ${ }^{28}$ ovat Schmittin mukaan vain mainioita satiirikkoja. Se, että kyse on välttämättä liberaaleista satiirikoista, johtuu siitä tosiasiasta, että parlamentarismi - keskustelun avulla hallitseminen - kuuluu liberalismin aatemaailman. Sen sijaan se ei Schmittin mukaan kuulu demokratiaan. On totta, että aluksi demokratia näytti liberalismin ilmeiseltä liittolaiselta, mutta sosiaalidemokratian myötä se liittoutui sosialismin kanssa aivan kuten se tällä vuosisadalla on liittoutunut kaikkien poliittisten suuntausten kanssa. Itse asiassa demokratia voi Schmittin mukaan aivan hyvin olla 
militaristinen tai pasifistinen, absolutistinen tai liberaali, keskitetty tai hajautettu, edistyksellinen tai taantumuksellinen. Tästä huolimatta kyse ei ole muodosta vailla substanssia, sillä demokratian olemus lepää - kuten on sanottu - samanlaisuutena (Gleichartigkeit) ymmärretyssä tasa-arvon (Gleichheit) käsitteessä. ${ }^{29}$

Schmittin mukaan demokratia ei toisin sanoen perustu keskusteluun - liberaalista perusoikeuksien julistuksesta, oikeusvaltiollisesta lain hallinnan ensisijaisuudesta ja vallanjaon ideasta tai aristokraattisesta edustuksellisuudesta puhumattakaan - vaan Aristoteleen klassiseen, samanlaisuutena ymmärrettyyn tasa-arvoisuuden periaatteeseen. ${ }^{30}$ Demokratioissa vain samanlaiset ovat tasa-arvoisia: "Tähän asti ihmiset, jotka ovat tavalla tai toisella täysin tai osittain olleet ilman oikeuksia ja joiden poliittista vallankäyttöä on rajoitettu - kutsutaan heitä sitten barbaareiksi, sivistymättömiksi, ateisteiksi, aristokraateiksi, vastavallankumouksellisiksi tai jopa orjiksi - ovat kuuluneet demokratiaan." 31 Tuo tasa-arvoisuuden perustana oleva samanlaisuus voi olla rodullista tai moraalista, uskonnollista tai kansallista, mutta ennen kaikkea se on rajallista ja rajoittavaa: "Tasa-arvoisuus ilman epätasa-arvoisuuden mahdollisuutta, tasa-arvoisuus jota on mahdotonta menettää, on arvotonta ja yhdentekevää." ${ }^{32}$ Schmittin mukaan kaikkien ihmisten tasa-arvo on toisin sanoen vain tyhjä muodollisuus eikä sen vaatiminen kuulu demokratiaan vaan liberalismin maailmankatsomukseen. Schmitt kyllä myöntää, että demokratia ja liberalismi on pitkään liitetty toisiinsa ja että jopa Rousseau, jonka Yhteiskuntasopimusta voidaan pitää demokraattisten periaatteiden johdonmukaisimpana esityksenä, lähtee liikkeelle liberalismille ominaisesta sopimuksen käsitteestä. Schmittin mukaan liberaalia tuossa teoksessa on kuitenkin vain pinta, sikäli kuin valtion legitimiteetti oikeutetaan vapaan sopimuksen avulla, mutta varsinainen sisältö viittaa demokraattiseen samanlaisuuden periaatteeseen. Yleistahdon keskeinen käsite ei suvaitse edes eriäviä mielipiteitä, vaan ne mielipiteet ja äänestyspäätökset, jotka poikkeavat yleistahdosta eli "enemmistön äänestä", ovat yksinkertaisesti vääriä. ${ }^{33}$ Näin se kansalainen, joka jättää noudattamatta yleistahtoa, ei voi enää olla kansalainen eikä tässä mielessä tasa-arvoinenkaan. Hän jää "muukalaiseksi kansalaisten keskelle".34

Demokraattinen tasa-arvo ei kuitenkaan ole vain alamaisten samanlaisuutta, rahvaan keskinäistä identtisyyttä, sillä se edellyttää yhtä lailla identtisyyden hallitsijoiden ja hallittujen - käskevien ja tottelevien - välillä. ${ }^{35}$ Demokratiassa suvereeni samastuu alamaiseen ja ainoastaan siinä määrin kuin niiden välillä on, kuten Rousseau vaati, "identtinen korrelaatio", ${ }^{36}$ voidaan puhua todellisesta demokratiasta. Samaa todistaa Pufendorf, jonka mukaan demokratiassa käskijät ja tottelijat ovat identtisiä. ${ }^{37}$ Schmittin mukaan voidaan puhua kokonaisesta identtisyyksien sarjasta: siihen kuuluvat - hallitsevien ja hallittujen tai suvereenin ja alamaisen identtisyyden ohella - valtiovallan subjektin ja objektin, kansan ja sen parlamentissa olevien edustajien, valtion ja äänestysikäisen väestön, valtion ja lain sekä lopuksi ja ennen kaikkea kvantitatiivisen eli lukumääräisen enemmistön tai yksimielisyyden ja kvalitatiivisen eli lakien oikeudenmukaisuuden identtisyys. ${ }^{38}$

Jo Pufendorf käsitti, että käskevien ja tottelevien identtisyydelle perustuvan demokraattisen poliittisen entiteetin valta on periaatteessa rajoittamatonta - sikäli kuin yksikään käskevien ja käskettyjen välinen - valtiovaltaa rajoittava - sopimus ei ole mahdollinen. ${ }^{39}$ Demokratiassa kansan tahto on välittömästi laki (lex est quod populus iussit) ja kaikki yritykset rajoittaa tämän tahdon ilmaisemista - vallanjaon tai muun vastaavan avulla - ovat, kuten Schmitt korostaa, väistämättä epädemokraattisia. ${ }^{40}$ Schmittin mukaan kansa ei kuitenkaan välttämättä tahdo parlamentarismia, eikä liberaali periaate, että kansa voi ilmaista tahtonsa vain äänestämällä salaisesti täydellisessä eristyksessä muista kansalaisista, ole mikään demokratiaan kuuluva idea: "Yksi- 
löllisellä ja salaisella äänellä suoritettu vaali tai äänestys tekee kansalaisesta ( citoyen $^{41}$ ) - tästä erityisen demokraattisesta eli politttisesta hahmosta - yksityisen alueelta peräisin olevan yksityisen ihmisen (Privatmann), joka äänensä antaessaan ilmaisee yksityisen mielipiteensä. ${ }^{\prime 22}$ Itse asiassa tällainen yksityisen alueella ja täydellisen vastuuttomuuden tilassa äänestäminen on ristiriidassa kansan koko käsitteen kanssa, joka Schmittin mukaan kuuluu julkisen alueelle: "Kansa näyttäytyy vain julkisen alueella." Eikä tällaisten äänten laskeminen näin ollen ilmaise julkista tai yleistä mielipidettä volonté générale - vaan miljoonien yksityishenkilöiden mielipiteen, joka äärimmilleen vietynä - sellaisessa jatkuvan äänestyksen tilassa, jonka nykyteknologia mahdollistaa - merkitsee valtion ja julkisen jäännöksetöntä privatisaatiota. ${ }^{44}$ Sitä paitsi, väittää Schmitt, yksikin ihminen voi ilmaista kansan tahdon siinä missä joukko kansanedustajia. Näin hän päätyy olettamukseen, että diktatoriset ja caesaristiset keinot eivät välttämättä ole antidemokraattisia, sillä ne voivat olla "demokraattisen substanssin ja voiman suora ilmaus". ${ }^{45} \mathrm{Ne}$ ovat ainoastaan antiliberaaleja.

EKSKURSSI :

REPRESENTAATIO JA IDENTITEETTI

Schmittin mukaan jokainen poliittinen muoto - valtio tai valtiomuoto (Staatsformen)voidaan määritellä sen mukaan, missä määrin sitä hallitsee identtisyyden ja missä määrin sille vastakkainen representaation idea, kuten hän teoksessaan Verfassungslehre (1928) kirjoittaa. Äärimmäiselle identtisyydelle perustuva muoto on suora tai välitön (unmittelbar) demokratia, äärimmäiselle representaatiolle perustuva muoto taas absoluuttinen monarkia. Täydellinen identtisyys tai kansan välitön läsnäolo itsensä kanssa - "kansan substantiaalinen homogeenisuus" - on Schmittin mukaan kuitenkin pelkkä fiktio, ja näin ollen valtio edellyttää aina representaation: "Ei ole valtiota ilman representaatiota." ${ }^{46}$ Representaatio viittaa vuorostaan näkyvyyteen, ja näin näkyvyytenä ymmärretystä julkisuudesta tulee Schmittille kaiken poliittisen vallan olennainen osa: "Representoida merkitsee näkymättömän tekemistä näkyväksi ja ajateltavissa olevaksi julkisesti läsnäolevan kautta." ${ }^{47}$ Tuo näkymätön on ennen muuta idea. Eikä idea tässä yhteydessä ole vähäpätöinen tekijä, sillä Schmittin mukaan jokainen poliittinen yksikkö - polis, keisarikunta, valtio - perustuu välttämättä idealle ja tämän idean representaatiolle. ${ }^{48}$

Representaatio tuo identtisyyden immanenttiin yöhön esille asettavan transsendenssin, mutta toisaalta ilman edellistä ei ole jälkimmäistäkään. Vaikka representaatio asettaa kansan esille valtiona, valtio toisaalta edellyttää kansan esivaltiollisena tai muodottomana - mutta tästä huolimatta poliittisena - yksikkönä. Valtio on aina poliittisena yksikkönä tai ykseytenä (Einheit) ymmärretyn kansan tila (status), ja näin täydellinen representaatio ilman kansaa on tyhjä: "Ei ole valtiota ilman kansaa." ${ }^{49}$ Toisin sanoen representaatio ja identiteetti edellyttävät toinen toistaan. Niiden suhde ei kuitenkaan ole vain täydentävä, sillä niiden välillä vallitsee, kuten Schmitt korostaa, jatkuva vastakkaisiin suuntiin vievä jännite. ${ }^{50}$ Nimenomaan tämä identiteetin tai puhtaan presentaation ja representaation - itselleen identtisen (immanentin) kansan ja erolle perustuvan (transsendentin) valtion - välinen yhteensovittamaton ja ylittämätön jännite perustaa poliittisen muodon poliittisena, valtiona tai valtiomuotona. ${ }^{51}$

On totta, että Schmitt tekee Weimarin tasavallan konstituutiota käsittelevässä Verfassungslehressään - toisin kuin yksinomaan suvereenisuutta käsittelevässä $P O$ liittisessa teologiassaan (1922) $)^{52}$ - nimenomaan kansasta suvereenin. Tämä demokraattinen suvereenisuus ei kuitenkaan monarkkisen suvereenisuuden tavoin ole representoivaa vaan, kuten Abbé Sieyès asian on ilmaissut, konstituution perustavaa valtaa (pouvoir constituant). Konstituoiva valta on kyllä suvereenia valtaa, sillä Schmittille suvereenisuus määrittyy sellai- 
sen järjestystä tai - tässä tapauksessa - konstituutiota koskevan "eksistentiaalisen päätöksen" kautta, joka tulee tuon järjestyksen tai konstituution ulkopuolelta. Demokratiassa juuri kansa nimenomaan edeltää konstituutiota tai on konstituution yläpuolella. ${ }^{53}$ Konstituoiva valta ei kuitenkaan yksinään vielä aseta poliittista muotoa, valtiota tai valtiomuotoa. Valtiomuodon olemassaolo edellyttää yhtä lailla konstituutiota säilyttävää valtaa (pouvoir constitué), ja tämä valta kuuluu eettisen perustan eli idean representoivalle poliittiselle auktoriteetille..$^{54}$

Toisin sanoen, jos valtion olemassaolo edellyttää muodottoman - muotoa antavan - elementin, järjestyksen luomiseen (Herstellung) viittaavan luonnollisen ja "organisoimattoman voiman", ${ }^{5}$ joka ilmplikoi vallankumouksen aina läsnä olevan reaalisen mahdollisuuden ja joka demokratiassa lankeaa epäilemättä kansalle, edellyttää se niin ikään esille asettamisen (Darstellung) aktin. Esille asettaminen ei kuitenkaan ole enää kansan tehtävä, ei demokratiassa eikä missään muussakaan valtiomuodossa, sillä se kuuluu poliittiselle auktoriteetille, hallitsijalle: "Jokaisessa valtiossa on oltava ihmisiä, jotka voivat sanoa: L'État c'est nous." ${ }^{56}$ Vain ne, jotka hallitsevat, ottavat osaa esille asettamiseen tai representaatioon. ${ }^{57}$ Ei kuitenkaan pidä luulla, että hallitseva auktoriteetti representoi kansaa, sillä kansa on muodoton ja organisoimaton - aina väistämättä poikkeustilaan viittaava - voima. Auktoriteetti representoi eettisen idean. Vain idea - viime kädessä representaation itsensä idea - tuo muodon ja organisaation: "Niin kauan kuin on olemassa edes idean haamu, on olemassa käsitys, että on jotakin arvokkaampaa kuin materiaalisten asioiden annettu todellisuus - että on olemassa jotakin transsendenttia - ja tämä merkitsee aina auktoriteettia ylhäältä."58

On totta, että kansaa, tätä konstituoivan vallan demokraattista subjektia, ei milloinkaan voi loppuun asti muotouttaa tai organisoida - mikä on seurausta absoluuttisesti vapaan suvereenin a priori -määrittymättömyydestä ${ }^{59}$ - mutta toisaalta kansa ei kos- kaan ole myöskään "kompentenssilla varustettu konstituoitu auktoriteetti". ${ }^{60}$ Se ei voi "neuvotella, harkita tai keskustella, se ei voi hallita eikä hallinnoida", se voi vain huutaa kyllä tai ei sille esitettyyn kysymykseen. ${ }^{61}$ Huutoäänestys - joka voi tapahtua hyväksynnän tai hylkäyksen huudahduksella, eläköön tai alas huutamalla, osoittamalla suosiota johtajalle tai esitykselle, toivottamalla pitkää ikää kuninkaalle tai kaikille muille henkilöille tai kieltäytymällä huutoäänestyksestä pysyen hiljaa tai mumisten $^{62}$ - on itse asiassa kansan tahdon välittömän ilmenemistavan luonnollinen muoto. ${ }^{63}$ Schmittille valtiomuoto, joka identiteetin ohella perustuu representaation idealle, ei sen sijaan ole milloinkaan vain luonnollinen: "Representaation idea perustuu siihen tosiasiaan, että poliittisena yksikkönä olemassa oleva kansa omaa korkeamman, ylevämmän ja intensiivisemmän tavan olla olemassa kuin tavalla tai toisella yhdessä elävän ihmisryhmän luonnollinen olemassaolo." ${ }^{64}$ Yksi ei kuitenkaan tule toimeen ilman toista, sillä vasta niiden jännite - luonnollisen ja idean, kansan ja representaation, immanentin ja transsendentin välinen peruuttamaton ja sovittamaton vastakohtaisuus - asettaa poliittisen muodon poliittisena ja muotona, valtion valtiona. Vasta jännitteisten ja ylittämättömien vastakohtien kompleksi, complexio oppositorum, luo todellisen inhimillisen järjestyksen. ${ }^{65}$

Schmittin representaation ideassa ei ole kyse nykyaikaisesta parlamentaarisesta edustuksellisuudesta, sillä hänen mukaansa representatiivisuus kuuluu julkisuuden alueelle eikä sillä ole mitään tekemistä salaisesti annettujen äänten tai sijaisuuden, valtuutuksen, mandaatin tai muiden vastaavien alunperin yksityisoikeudellisten käsitteiden kanssa. Sitä paitsi kaikki se, mitä nykyaikainen kansanedustaja - toisin kuin vielä 1800-luvulla - hänen mukaansa edustaa, liittyy usein yksinomaan puolueohjelmiin, aineellisiin intresseihin ja laskennalliseen äänestäjäkuntaan. Todellinen representatiivisuus edellyttää puolueellisen, materiaalisen ja laskennallisen sijaan kuiten- 
kin kokonaisuuteen - kansakuntaan - liittyvän, henkisen ja laadullisen. ${ }^{66}$ Itse asiassa Schmitt ei kutsu intressien edustamista representaatioksi (Repräsentation) lainkaan vaan käyttää siitä käsitettä Vertretung. Ei kuitenkaan pidä luulla, että tällainen - turmeltunut - edustuksellisuus tuhoaa demokratian. Schmitt päinvastoin lakkaamatta korostaa, että aineellisia intressejä edustavat - kansan asiamiehinä ymmärretyt - puolueet tai ammattiyhdistykset ilmaisevat jopa paremmin demokraattisen identiteettiperiaatteen kuin parlamentti, joka representatiivisine ideaaleineen kohoaa väistämättä kansan yläpuolelle: "Ei ole demokratiaa ilman puolueita. ${ }^{97}$

Demokratian periaate ei siis ole representatiivisuudessa vaan hallitsevien ja hallittujen tahdon identtisyydessä. Schmittin mukaan todellisuus kuitenkin vain harvoin vastaa periaatetta. Sikäli kuin todellisuus ja periaate eivät kohtaa, nousee esiin ratkaiseva kysymys kansan tahdon muodostamisesta - eli siitä, miten hallitsevat kykenevät esittämään oman tahtonsa hallittujen tahtona. Kyse ei toisin sanoen ole ensisijassa kansan tahdosta vaan mielipiteenmuodostamisesta. Moderniteetissa jokainen osapuoli väittää edustavansa kansan tahtoa, mutta konkreettisen elämän filosofian näkökulmasta ratkaisevin kysymys kuuluu, kuka hallitsee propagandakoneistoa eli niitä välineitä - "suurten massojen psykoteknisen manipulaation metodeja" ${ }^{18}$-, joilla kansan tahto on määrä muodostaa. ${ }^{69}$ Tämän koneiston - sotilasvoimien, poliisivoimien, julkista mielipidettä hallitsevan lehdistön, puolueiden, koulujen - hallitsijat muodostavat uuden aristokratian, jonka ensimmäinen poliittinen ohjelma koskee väistämättä kansalaiskasvatusta. Kansa ilmaisee oman tahtonsa oikealla tavalla vain oikean kasvatuksen ansiosta. Schmittin mukaan tämän kasvatusteorian seurauksena on diktatuuri, joka lykkää demokratiaa todellisen demokratian nimissä, joka on vasta tulossa. ${ }^{70}$ Hänen mukaansa tämä ei kuitenkaan tuhoa demokratiaa, sillä se vain osoittaa, että diktatuuri ei ole demokratian vastakohta. Sen sijaan se Schmittin mukaan tulee aivan hyvin toimeen ilman parlamentarismia ja sen avoimuuteen ja keskusteluun liittyviä periaatteita.

\section{DIKTATUURI JA MYYTTI}

Schmittin mukaan parlamentarismin metafyysinen perusta, "viimekätinen aatteellinen perusta" l1 lepää uskossa julkiseen keskusteluun, mielipiteiden esteettömään vaihtoon. Avoimuudesta Schmittin mukaan tulee absoluuttinen arvo ja julkisesta mielipiteestä valtaa kontrolloiva voima. Vain avoin keskustelu, kilpailevien näkökulmien kohtaaminen ja parhaimpien argumenttien asettuminen suhteellisena totuutena - ajatus jonka Jürgen Habermas on vienyt metafyysiseen huippuunsa - voi ylittää paljaan vallan ja voiman..$^{72}$ Schmittin mukaan todellinen valta, suuret poliittiset ja taloudelliset päätökset, joilla ihmiskunnan kohtalo nykyään lepää, eivät kuitenkaan kumpua tasapainoilevista mielipiteistä julkisessa keskustelussa vaan aivan muualta. Se, mistä valikoituneet puoluekomiteat tai suurpääoman edustajat sopivat suljettujen ovien takana, on kenties tärkeämpää miljoonien ihmisten kohtalon kannalta kuin mikään julkinen keskustelu tai parlamentaarinen päätöksenteko. ${ }^{73}$

Tätä parlamentarismin periaatteiden ja ihmisten todellisen kohtalon välistä kuilua nousi 1800-luvulla välittämään yhtäältä demokratian, toisaalta diktatuurin idea. Sekä demokratia - anarkismi ja sosialismi että diktatuuri asettuivat yhdessä porvarillista liberalismia ja parlamentarismia vastaan. Keskustelu, tasapainottelu, julkiseen elämään osallistuminen - tämä ajattelu seisoi Schmittin mukaan näiden kahden vastustajansa välissä, jotka asettuivat sitä vastaan sellaisella voimalla, että koko välittävän keskustelun idea näytti olevan ainoastaan verisen taistelun väliaika. Molempien vastustajien vastaus tähän keskusteluun oli välitön ja varma kaikkien tasapainojen tuho. 
Sosialismin aatteista marxismin poliittinen nerokkuus ja voitokkuuden salaisuus oli sen kyvyssä yhdistää rahvaan valtana ymmärretty demokratia diktatoristen periaatteiden kanssa. Schmittin mukaan proletariaatin diktatuuria, jota Engels jo AntiDühringissä ehdottaa, ei kuitenkaan voida nähdä vain välittömän päätöksenteon affirmaationa välittävää keskustelua vastaan, sillä sen, kuten Marxin ajattelun yleensä, taustalla on valistuksen ajatus järjen diktatuurista, "filosofian ja miekan" allianssista. Condorcet'n tavoin Marx uskoi, että vain historiallisen totuuden saavuttaminen teoriassa oikeutti voimankäyttöön käytännössä. Tieteellisen totuuden tason saavuttanut teoria osoitti toiminnan välttämättömän laadun. Tämän takia proletariaatin diktatuuri, niin kuin Engels sen hahmottaa, ei ole Schmittin määritelmän mukaan diktatuuri vaan rationalistinen tyrannia, jonka diktaattori on johtava rationalisti. ${ }^{74}$

Marxin alkuperäisyys poliittisena ajattelijana ei Schmittin mukaan olekaan hänen "tieteellisen sosialismin" ohjelmassaan vaan siinä tavassa, jolla hän kykenee asettamaan esille poliittisen konfliktin kaikessa yksinkertaisuudessaan. Ihmiskunta palautetaan ystävään ja viholliseen, työväenluokkaan ja porvaristoon, joka viimeisessä taistossa luvataan tuhota kokonaan. Porvaristosta tulee työväenluokan absoluuttinen vihollinen, ja vasta absoluuttinen sota voi antaa paikan valtiottomalle universaali-yhteiskunnalle ilman luokkia. ${ }^{75}$ Tästä huolimatta marxilainen proletariaatin diktatuuri pitää vielä sisällään rationalistisen diktatuurin mahdollisuuden. Sen sijaan kaikki modernit suoran toiminnan ja voimankäytön teoriat lepäävät Schmittin mukaan enemmän tai vähemmän tietoisesti irrationaalisella perustalla. Järjellisen kehityksen sijaan astuu vietti ja intuitio, tietoisen sijaan tiedostamaton. Jo Bakunin vannoi mieluummin taiteen kuin tieteen nimeen, sillä se on lähempänä todellista elämää kuin tiede. Tieteellä ei ole oikeutta hallita, sillä se ei ole elämää, se ei luo mitään ja se ymmärtää vain yleisen ja abstraktin uhraten yksilöllisen elämäntäyteyden abstraktioiden altta- rilla. Elämä tuottaa abstrakteja reflektioita, mutta nuo reflektiot eivät koskaan kykene tuottamaan elämää. ${ }^{76}$

Bakunin vastustaa Marxin uskoa tieteeseen - tieteelliseen sosialismiin - mutta ei vain sen takia, että tiede on abstraktia, vaan yhtä lailla siksi, että tiede voi olla vain joidenkin harvojen yksinoikeus, kun taas kansa, jonka puolesta Bakunin puhuu, on ja tulee olemaan välinpitämätön sen suhteen. Jos tiede hallitsee, ei hallitse vain abstrakti ja yleinen vaan samalla tieteentekijöiden pieni vähemmistö: "Jos tieteen on määrä laatia elämän lait, silloin muutaman sadan oppineen täytyy hallita ihmiskunnan suurta enemmistöä, miljoonia ihmisiä.,"77 Bakuninille proletariaatin diktatuuri ei ole muuta kuin pienen, itseään oppineena pitävän uuden aristokratian despotiaa. Sitä paitsi hallitsevan proletariaatin täytyy löytää itselleen ne, joita hallitaan. Näin syntyy uusi proletariaatti, jonka täytyy jälleen alistua. Voi olla, että tässä diktatuurissa on kyse välivaiheesta matkalla kohti todellista sosialismia, mutta Bakunin ei ymmärrä tällaistakaan puhetta. Jos lopullisena päämääränä on kansan vapaus, minkä takia se täytyy ensin orjuuttaa?78

Valtion sijaan - valtion jonka "päivät ovat luetut"79 - Bakunin vannoo kansan vapaaehtoisten taloudellisten yhdistysten nimeen. Ammattiyhdistys nousee työväestön elämän välittömistä ja todellisista tarpeista - "alhaalta ylöspäin" - ja tämä sosiaaliseen vaistoon sidottu välittömyys oikeuttaa syndikalismin. Kuitenkin vasta Georges Sorel, joka yrittää perustaa poliittisen ajattelunsa Henri Bergsonin elämänfilosofiaan, kykenee kohottamaan suoran toiminnan teorian myytin tasolle. Soreliin nähden Marx oli Schmittin mukaan vain koulumestari, joka jäi länsimaisen porvarillisen sivistyksen loukkoon.

Sorelin mukaan toimintakyky ja sankaruus, kaikki suuret maailmanhistorialliset teot, perustuvat myytin mahtiin. Esimerkkejä tällaisista myyteistä ovat kreikkalaisten käsitys maineesta ja suuresta nimestä, muinaiskristillisyyden viimeisen tuomion odotus, Ranskan vallankumouksen aikana usko 
hyveeseen ja vallankumoukselliseen vapauteen sekä kansallinen innostus vuoden 1813 Saksassa. Sorelin mukaan ainoastaan elämänvaiston syvyydestä eikä järjestä tai pragmaattisista laskelmista virtaa suuri innostus, suuri moraalinen päätös ja suuri myytti. Ratkaiseva kysymys kuuluu, kenellä on nykyään kyky myyttiin? Sorelin mukaan vain sosialistisilla joukoilla, teollisuusproletariaatilla on myytti, johon se todella uskoo. Kun otetaan huomioon, että vuosisadan alun läntinen maailma oli ennen kaikkea tuotannon maailma, ei ole ihme, että Sorelille tuo myytti oli yleislakko, tuotannon laiton keskeyttäminen, poikkeustilan aiheuttaminen tuotannon normaalissa jatkuvuudessa.

Sorelin mukaan yleislakko ei kuitenkaan ole vain katkos tuotantoprosessissa, sillä se on ennen kaikkea "sodan ilmiö". ${ }^{80}$ Se ei ilmaise kauppasuhteissa tapahtunutta hetkellistä viivästymistä, sillä myytin asteelle kohotetussa yleislakon ideassa on kyse proletariaatin koko olemassaolosta. ${ }^{81}$ Sorelin mielestä nimenomaan myytti kaikkien utopioiden sijaan on paras "tulevaisuuden kehystämisen keino". ${ }^{2}$ Tosiasiassa myytti on kaikilta osin utopian vastakohta, sillä utopia on aina intellektuaalinen saavutus, rationalistinen illuusio, kun taas myytti viittaa elämän vaistonvaraiseen välittömyyteen. Eikä sitä tule arvioida niinkään tulevaisuuden vaan nykyisyyden suhteen - miten se palvelee nykyhetkessä tapahtuvaa poliittista toimintaa. 83 Tämä toiminta - "suuri taistelu" - ei Sorelin mukaan tule koskaan olemaan akateemisen strategian aikaansaannosta vaan useiden sankarillisten urotöiden ja yksilöllisten voimien vapautumisen tulos. Kyse ei enää ole mistään diktatuurista, sillä Bakuninin tavoin Sorel vihaa kaikkea militarismia ja keskittämistä. Diktatuuri ei ole mitään muuta kuin sotilaallis-byrokraattinen kone, joka syntyy rationalistisesta hengestä, kun taas massojen vallankumouksellinen voimankäyttö on välittömän elämän ilmaus. Se voi olla villi ja barbaarinen, mutta ei koskaan järjestelmällisesti hirvittävä ja epäinhimillinen.

Schmittin mukaan myyttiin perustuvan suoran toiminnan teoria saa konkreettisen ilmauksensa Venäjän vallankumouksessa, mutta sen myytti ei ole yksinomaan luokkataistelu vaan samalla kansallinen. Sosialismi voitti Venäjällä vain sen takia, että se kykeni yhdistämään luokkataistelun kansallistunteeseen, jonka vihan kohteena ei ollut niinkään omistava luokka kuin länsimainen intellektualismi. Vallankumouksen jälkeen Venäjästä tuli jälleen venäläinen ja Moskovasta sen pääkaupunki. Leninin suurimpana ansiona oli nimenomaan katkaista Pietari Suuren käynnistämä Venäjän länsimaistaminen. Schmittin mukaan tämä osoittaa, että luokkakonfliktia suurempi myytti on lopulta nationalismi: "Mitä luontoperäisempi käsitys rodusta ja suvusta, sitä ilmeisempi kelttiläisille ja romaanisille kansoille tyypillinen 'terrismi'; kieli, traditio, tietoisuus jaetusta kulttuurista ja kasvatuksesta, tietoisuus yhteisestä kohtalosta, tunne erilaisuudesta sellaisenaan - kaikki tämä johtaa kohti kansallista pikemminkin kuin luokkatietoisuutta nykyään."

Tämän takia Mussolini on Schmittin mukaan lopulta vahvempi kuin Lenin, sillä hänen ei tarvitse yhdistää kansainvälistä luokkakonfliktia kansallistunteeseen vaan hän voi suoraan vedota kansalliseen myyttiin. Sillä Sorelin hahmotteleman syndikalismin tavoin fasismin perustana on myytti, ei kuitenkaan edelleenkään mikään menneisyyden tarina, vaan uusi myytti, joka tulee luoda. Sen ei tarvitse olla todellisuutta vaan pyrkimystä ja toivoa, uskoa ja rohkeutta. Mussolinin myytti on suuri myyttinen kansakunta, josta tulee tehdä konkreettista todellisuutta. ${ }^{85}$ Näin anarkismin myyttistä muotoa, joka asettuu vastustamaan kaikkia auktoriteetteja ja kaikkea ykseyttä, vastaan asettuu uusi tunne järjestyksestä, kurista ja hierarkiasta. On itse asiassa sama kumpi lopulta voittaa, Schmittin mukaan on joka tapauksessa selvää, että myytin teoria on kaikkein selkein oire ei vain kasvatusdiktatuurin absoluuttisen rationalismin vaan myös parlamentaarisen ajattelun suhteellisen rationalismin rappiosta. 
1. Vielä Weimarin kaudella Schmitt yhtyi espanjalaiseen vastavallankumoukselliseen ja katoliseen Donoso Cortésiin, jonka mukaan anarkia oli suurin paha, jota vastaan oli asetettava auktoritetti, mutta toisen maailmansodan jälkeen Schmitt, tämä entinen natsi ja natsi-Saksan laajentumispolitiikan suunnittelusta epäilty yksityisajattelija kuitenkin kirjoittaa: "Anarkistinen kaaos on parempi kuin nihilistinen sentralisaatio. Katechon [so. Antikristuksen maailmanhallinnan vastavoima] voidaan havaita hänessä, joka ei aja maailman ykseyden asiaa." Carl Schmitt, Glossarium - Aufzeichnungen der Jahre 1947 1951. Duncker \& Humblot 1991, s. 165. Eikä anarkiassa ole kyse vain pienemmästä pahasta, sillä modernien joukkotuhoaseiden palveluksessa olevan keskitetyn nihilistisen järjestyksen aikakaudella se saattaa epätoivoiselle ihmiskunnalle näyttää, kuten Schmitt kirjoittaa, "tehokkaalta parannuskeinona". Carl Schmitt, Donoso Cortés in gesamteuropäischer Interpretation - Vier Aufsätze. Greven Verlag 1950, s. 13.

2. Carl Schmitt, Der Begriff des Politischen. Text von 1932 mit einem Vorwort und drei Corollarien. Duncker \& Humblot 1979(1932), s. 61. Näin Schmitt yhtyy paitsi vastavallankumouksen teoreetikkoihin de Maistreen (jolle sota ja jatkuva verenvuodatus on ihmiskunnan historiassa pikemminkin sääntö kuin poikkeus) ja edellä mainittuun Donoso Cortésiin (joka radikalisoi perisyntiopin opiksi ihmisluonnon absoluuttisesta syntisyydestä ja hylätyksi joutuneisuudesta) myös Machiavelliin, jonka mukaan valtion järjestäjän ja lainlaatijan on oletettava, "että kaikki ihmiset ovat pahoja ja että he aina seuraavat pahaa luonnettaan, milloin vain saavat siihen tilaisuuden". Ks. Joseph de Maistre, Considerations on France. Cambridge University Press 1994, s. 23-31; Juan Donoso Cortés, "Discorso sobre la dictatura". Teoksessa Obras Completas. Vol II. Editorial Católica 1970; Niccolo Machiavelli, Valtiollisia mietteitä. WSOY 1998, I kirja, III kappale, s. 24.

3. Schmittin epäilemättä kuuluisimman teesin mukaan poliittisen sfäärin olemassaolon edellytyksenä on sodan todelliselle mahdollisuudelle perustuva jako ystävään ja viholliseen. Tämä ei kuitenkaan tarkoita, että Schmitt samastaisi sodan ja politiikan, kuten usein näkee väitettävän, sillä sodan olemus on vihollisen negaatio, kun taas politiikka viittaa ihmisryhmien väliseen jännitteeseen tai jännitteen asteeseen, joka viime kädessä $v o i$ johtaa sotaan. Sota loppuu, kun vihollinen tuhotaan tai päästään rauhansopimukseen, mutta poliittinen loppuu vasta kun on hävitetty vihollisuuden koko olemassaolon mahdollisuus - toisin sanoen kun on saavutettu ikuisen rauhan todellinen tilanne. Schmittin mukaan tämän tilanteen saavuttaminen edellyttää kuitenkin ihmiskunnan absoluuttista passivoitumista. Ks. Schmitt, Der Begriff des Politischen, s. 28-37.

4. Carl Schmitt, Gespräch über die Macht und den Zugang zum Machthaber. Günther Neske 1954, s. 4. Schmittin mukaan protego ergo obligo onkin valtion cogito ergo sum ja poliittinen teoria, joka ei systemaattisesti ole tietoinen tästä lauseesta, jää välttämättä riittämättömäksi reunahuomautukseksi. Schmitt, Der Begriff des Politischen, s. 53.

5. Thomas Paine, Common Sense. Teoksessa Political Writings. Cambridge University Press 1989, s. 3.

6. Schmitt, Der Begriff des Politischen, s. 70.

7. Mt., s. 61.

8. Mt., s. 76-77.

9. Carl Schmitt, "Weiterentwicklung des totalen Staats in Deutschland" (1933). Teoksessa Verfassungsrechtliche Aufsätze aus den Jahren 1924-1954. Materialien zu einer Verfassungslehre. Duncker \& Humblot 1958, s. 361.

10. Carl Schmitt, Der Hüter der Verfassung. Duncker \& Humblot 1931, s. 79.

11. Schmitt, Der Begriff des Politischen, s. 24.

12. Schmitt kirjoittaa: "Tämä 'totaalinen valtio' voidaan torjua vihan ja närkästyksen vallassa barbaarisena, slaavilaisena, epäsaksalaisena tai epäkristillisenä, mutta asia itse ei tämän takia kuitenkaan häviä maailmasta." Schmitt, "Weiterentwicklung des totalen Staats", s. 360.

13. Schmittin mukaan jokaisella aikakaudella on sille ominaisia ja itsestään selviä käsityksiä politiikasta ja meidän aikakaudellamme tuo kyseenalaistamaton käsitys on demokratian ylivoimaisuus suhteessa muihin valtiomuotoihin: "Poliittisen ja valtioteorian historia 1800-luvulla voidaan kiteyttää yhteen iskulauseeseen: demokratian voittokulku." Carl 
Schmitt, Die geistesgeschichtliche Lage des heutigen Parlamentarismus. Toinen painos. Duncker \& Humblot 1926(1923), s. 30. Demokratia pikemminkin kuin mikään kommunismi - joka sekin esiintyy mielellään demokratian nimissä - on aikamme ylittämätön horisontti.

14. Schmitt piti 1930-luvun alun Saksan valtiota nimenomaan kvantitatiivisena totaalisena valtiona: "Nykyinen Saksan valtio on totaalinen sen heikkouden ja vastustuskyvyn puutteen takia, kyvyttömyydestä vastustaa puolueiden ja organisoituneiden intressien hyökkäyksiä." Schmitt, "Weiterentwicklung des totalen Staats", s. 362.

15. Jos asetus on motorisoitu laki, on direktiivi - tämä lainsäädännön joustavin muoto, joka nopeudessaan ja yksinkertaisuudessaan ylittää jopa asetuksen - Schmittin mukaan "motorisoitu asetus". Hallintovaltiossa laista tulee vain suunnittelun väline, hallinnollinen toimenpide, joka voidaan muuttaa yhdessä yössä ja sovittaa nopeasti muuttuviin olosuhteisiin. Ks. Carl Schmitt, "Die Lage der europäischen Rechtswissenschaft" (1943 144). Teoksessa Verfassungsrechtliche Aufsätze aus den Jahren 1924-1954. Materialien zu einer Verfassungslehre. Duncker \& Humblot 1958, s. 407.

16. Carl Schmitt, Legalität und Legitimität. Teoksessa Verfassungsrechtliche Aufsätze aus den Jahren 1924-1954. Materialien zu einer Verfassungslehre. Duncker \& Humblot 1958(1932), s. 263-274.

17. Schmitt, "Weiterentwicklung des totalen Staats", s. 361.

18. Carl Schmitt, "Strong State and Sound Economy". Liite teoksessa Renato Cristi, Carl Schmitt and authoritarian liberalism. University of Wales Press 1998, s. 213.

19. Mt., s. 227.

20. Schmitt, "Weiterentwicklung des totalen Staats", s. 361.

21. Mt.

22. "Fasistinen valtio on jälleen perinteinen nuhteeton valtio näkyvine johtajineen ja edustajineen eikä näkymättömien ja vastuuttomien hallitsijoiden ja pankkiirien fasadi ja Antichambre." Carl Schmitt, "Wesen und Werden des faschistischen Staates" (1929). Teoksessa Positionen und Begriffe im Kampf mit Weimar, Genf, Versailles. 1923-1939. Duncker \& Humblot 1985, s. 113-114.

23. Mt., s. 111. Schmitt kyllä myöntää, että ylei- nen äänioikeus kuuluu demokratiaan, mutta hän ei pidä sitä demokraattisen tasa-arvon sisältönä vaan ennalta oletetun tasa-arvon seurauksena. Ks. Carl Schmitt, Verfassungslehre. Duncker \& Humblot 1965(1928), s. 227.

24. Schmitt, Verfassungslehre, s. 83-84.

25. Schmitt määrittelee demokratian "julkisen mielipiteen ylivaltana" ja korostaa, että demokratian poliittinen luonne perustuu nimenomaan julkisen ensisijaisuuteen suhteessa yksityiseen. Mt., s. 246, 255.

26. Schmitt, Parlamentarismus, s. 10.

27. Mt., s. 11.

28. Lainaus, mt., s. 12.

29. Ks. erit. Schmitt, Verfassungslehre, s. 226234.

30. Aristoteleen mukaan "tasa-arvo tarkoittaa saman antamista samanlaisille". Aristoteles, Politiikka. Gaudeamus 1991, 1332 b27.

31. Schmitt, Parlamentarismus, s. 15.

32. Schmitt, Verfassungslehre, s. 227.

33. "Milloin minun mielipiteeni vastakkainen mielipide voittaa, niin osoittaa se vain sitä, että minä olin erehtynyt." Jean-Jacques Rousseau, Yhteiskuntasopimuksesta. Karisto 1988, IV kirja, II luku, s. 170.

34. Mt., IV kirja, II luku, s. 169.

35. Schmitt, Verfassungslehre, s. 234.

36. Rousseau, Yhteiskuntasopimuksesta, III kirja, XIII luku, s. 149. Käännöstä muutettu.

37. Ks. Samuel Pufendorf, Le Droit de la nature et des Gens. E \& J.R. Hourneisen 1732, VII kirja, VI luku, $₫ 8$.

38. Schmitt, Parlamentarismus, s. 26.

39. Pufendorf ajatteli, että sama henkilö ei voi olla yhtä aikaa käskijä ja tottelija, mutta Rousseau, kuten tunnettua, tekee nimenomaan jaetusta henkilöstä oman valtionsa perustan. Sopiminen on edelleen mahdollista, mutta tällä kertaa se tapahtuu itsen kanssa: kansalainen alamaisena tottelee kansalaista suvereenina, joka suojelee häntä ihmisenä. Käskeminen ja totteleminen ei häviä minnekään, mutta kukin "käskee ja tottelee vain itseään”. Ks. Rousseau, Yhteiskuntasopimuksesta, erit., s. 42-44.

40. Schmitt, Parlamentarismus, s. 20.

41. Schmitt käyttää useaan otteeseen ranskalaista kansalaisen (citoyen) käsitettä, koska saksan kielen Bürger sekoittaa kansalaisen ja porvarin - vaikka hänen mukaansa näiden kahden välinen vastakohtaisuus on vähintään yhtä voimakas kuin vastakohtaisuus epäpoliittisen eettis-taloudellisen liberalismin ja puh- 
taasti poliittisen demokratian käsitteiden välillä. Schmitt, Verfassungslehre, s. 253.

42. Mt., s. 245. Schmittin mukaan vaalisalaisuutta ei kuitenkaan pidä sekoittaa todelliseen eli valtionsalaisuuteen, sillä toisin kuin virkamieheltä edellytetty salassapito, joka on velvollisuus, on tuon salaisuuden pitäminen yksinomaan kansalaisen oikeus.

43. Mt., s. 243; ks. myös esim. Schmitt, Parlamentarismus, s. 22.

44. Schmitt, Verfassungslehre, s. 245-246. Schmittin mukaan (kuten hän vastauksessaan Weberin Protestanttiseen etiikkaan kirjoittaa) tämän privatisaation alkuperää on etsittävä uskonnosta, sikäli kuin protestantismin synty merkitsee kirkon poliittisen eli representatiivisen välitystehtävän rappiota ja yksityisen - välittömän - Jumala-suhteen ilmaantumista: "Se tosiasia, että uskonto on yksityisasia, antaa yksityisyydelle uskonnollisen oikeutuksen." Carl Schmitt, Roman Catholism and Political Form. Greenwood Press 1996(1923), s. 28-29.

45. Schmitt, Parlamentarismus, s. 23.

46. Schmitt, Verfassungslehre, s. 206-207, 214. Tässä mielessä puhdas demokratia - ilman monarkkisia tai aristokraattisia piirteitä - on valtiomuotona mahdoton: "Ei missään eikä minään hetkenä ole olemassa poliittisena yksikkönä ymmärrettyä itselleen läsnä olevan kansan totaalista ja täydellistä identiteettiä. Kaikkien yritysten toteuttaa puhdasta tai välitöntä demokratiaa tulee ottaa huomioon tämä demokraattisen identiteetin rajoitus. Muuten välitön demokratia johtaa poliittisen yksikön tuhoutumiseen.” Mt., s. 207.

47. Mt., s. 209.

48. "Poliittiseen kuuluu idea, sillä ilman auktoriteettia ei ole politiikkaa ja ilman vakaumuksen henkeä [so. ideaa] ei ole auktoriteettia." Schmitt, Roman Catholicism, s. 17.

49. Schmitt, Verfassungslehre, s. 205.

50. "Representaation idealle rakentuvan järjestelmän johdonmukaisuus on toinen kuin itselleen identtisen suvereenin kansan plebisitääris-demokraattinen johdonmukaisuus, joka on välittömästi läsnä." Schmitt, Legalität und Legitimität, s. 315.

51. Schmitt toisin sanoen toistaa Platonin Laeissaan tunnetuksi tekemää väitettä, jonka mukaan valtiojärjestyksissä on kaksi kantamuotoa, kuningasvalta ja kansanvalta, joista kaikki muut juontuvat. Platonin mukaan jokaisessa hyvin hallitussa valtiossa, jossa vallitsee "vapaus, sopu ja järkevyys", on välttämättä aineksia molemmista. Platon, Lait. Otava 1986, 693d-e. Schmitt vie tämän idean kuitenkin pidemmälle. Hänen mukaansa sellaista valtiota ei ole olemassakaan, jossa ei olisi aineksia molemmista kantamuodoista.

52. Tässä Schmitt määrittelee suvereenisuuden poikkeustilaa koskevan persoonallisen päätöksen avulla ja korostaa, että kansa ei ole persoona eikä näin ollen voi tällaista päätöstä tehdä. Ks. Carl Schmitt, Poliittinen teologia. Neljä lukua suvereenisuusopista. Tutkijaliitto 1997, s. 95-97.

53. Demokratiassa kansa on "vor und über der Verfassung”. Schmitt, Verfassungslehre, s. 238.

54. Schmitt käyttää teoksestaan Die Diktatur (1921) lähtien toistuvasti tätä Abbé Sieyèsin jaottelua constituant/constitué. Schmittille konstituoiva valta (pouvoir constituant tai verfassunggebende Gewalt) - jonka Sieyès osoittaa kansalle tai kansakunnalle - on valtaa, jota konstituutio ei perusta, mutta jota se tästä huolimatta edellyttää. Suvereenin tavoin konstituoiva valta seisoo konstituution ulko- ja yläpuolella - siihen kuitenkin kuuluen. Ks. Schmitt, Verfassungslehre, s. 82-87; ks. myös Carl Schmitt, Die Diktatur. Von den Anfängen des modernen Souveränitätsgedankens bis zum proletarischen Klassenkampf. Duncker \& Humblot 1928(1921), s. 136-259. Käsitteen sosiologisesta näkökulmasta on mielenkiintoista, että metafysiikassa vastaava ero löytyy nimenomaan ensimmäiseltä todelliselta panteistilta ja immanenssin ajattelijalta ja tässä mielessä ensimmäiseltä filosofi-ateistilta - yhtä lailla Sieyèsin kuin Schmittin tässä yhteydessä viittaamalta ja jälkimmäisen natsikaudellaan ahkerasti kritisoimalta - juutalaiselta Baruch Spinozalta, joka erottaa toisistaan (Jumalaa ilmaisevien substanssin attribuuttien) luovan luonnon (natura naturans) ja (Jumalan attribuuttien moduksien) luodun luonnon (natura naturata). Ks. Baruch Spinoza, Etiikka. Gaudeamus 1994, s. 69-70.

55. Schmitt, Verfassungslehre, s. 83.

56. Mt., s. 207. Edes kaikki agoralle kerääntyneet kansalaiset eivät ole koko kansa vaan itse asiassa vain representoivat poliittisena yksikkönä ymmärrettyä kansaa, joka sekä laajuudeltaan että kestoltaan on enemmän kuin tämä yhteenkerääntynyt joukko. Ks. mt., s. 343.

57. Mt., s. 212.

58. Schmitt, Roman Catholism, s. 27. 
59. Suvereenin päätöksen a priori -määrittymättömyydestä ks. Schmitt, Poliittinen teologia, s. 77-78.

60. Schmitt, Verfassungslehre, s. 84. "Demokratiassa kansaa ei voida muuttaa auktoriteetiksi tai yksinkertaiseksi valtion 'elimeksi'." Kansa on aina enemmän kuin kompetenssin pohjalta toimiva auktoriteetti, jonka tarkoituksena on ratkaista oman alansa asioita. Mt., s. 242.

61. Schmitt, Legalität und Legitimität, s. 340. Tässä kuten lähes kaikissa demokratiaan liittyvissä kysymyksissä - tasa-arvoisuus samanlaisuutena, huutoäänestys, yleisen mielipiteen ylivalta ja niin edelleen - Schmitt turvautuu Rousseauhon, jonka mukaan vain jumalten muodostamalla kansalla on demokraattinen hallitus. Ks. Rousseau, Yhteiskuntasopimuksesta, s. 115.

62. Schmitt, Verfassungslehre, s. 243-244.

63. Mt., s. 83.

64. Mt., s. 347.

65. Tämän takia Schmittin valtio-oppia ei kenties pitäisi sekoittaa siihen Philippe LacoueLabarthen teoksessaan La fiction du politique analysoimaan "totalitaristiseen logiikkaan" - sellaiseen esteettiseen politiikkaan, jonka pohjalla on ajatus kaiken muovautuvuudesta (Schmitt ei kritisoi mitään niin rankalla kädellä kuin kaiken muovattavuuden "saatanallista" ajatusta - siitä huolimatta että hän päätyy tunnistamaan politiikan totaalina) ja joka ymmärtää valtion kansan ennalta oletetun identiteetin (sisällön) representaationa (muotona) - sellaisena taideteoksena tai työnä (cuvre), jossa itselleen identtinen kansa, Schmittin käsitteitä käyttääkseni, ilmaisee (representoi) oman identiteettinsä itselleen. Näin transsendentti, palatakseni jälleen Schmittin käsitteisiin, sulautetaan immanenssiin ja "auktoriteetin ylhäältä" korvaa immanenssin itsensä - mekaaninen (liberalismi) tai orgaaninen (kansallissosialismi) - (kvasitranssendentti) laki. Jean-Luc Nancyn mukaan, kuten hän teoksessaan $L a$ communauté désœuvrée korostaa, tämä johtaa "immanenssin aboslutisaatioon" ja lopulta yhteisönä ymmärretyn kansan itsemurhaan. Sillä absoluuttisen immanenssin yhteisö, joka oman representaationsa mukaan on puhdasta presentaatiota, ei voi hyväksyä minkäänlaista eroa ja eron voi tuhota lopullisesti vain kuolema. On totta, että Schmittille nykyaikainen valtio on, kuten on sanottu, totaalinen valtio, jossa kansa (immanenssi) ja valtio (transsendenssi) sekoittuvat jäännöksettä toisiinsa, mutta hänen Verfassungslehreään voi lukea nimenomaan totaalisen valtion kritiikkinä. Vaikka Schmitt sanoo valtion olevan identiteetin ja representaation yhdistelmä, ei tämä merkitse niiden yhdistymistä valtiossa tai jossain muussa myyttisessä yhteisössä - "fusion communielle", kuten Nancy sanoo. Schmittille representaatio merkitsee päinvastoin identiteetin ylittävän ja sille vastakkaisen idean representaatiota. Eikä tämä idea ole mikään tulevan kansan muoto, luonnollisen identiteetin - tuhoten tai säilyttäen - korvaava kansallisen tai jonkin muun identiteetin idea, jonka valtiotaide synnyttää ja jonka tuloksena on identiteetin ja representaation identiteetti "valtiossa taideteoksena". Kyse on monien yhdistelmästä ilman yhteensulauttavaa yhtä tai edes korkeampaa kolmatta - eli ylittämättömien ja sovittamattomien vastakohtien kompleksista. Ks. Philippe Lacoue-Labarthe, La fiction du politique. Christian Bourgois 1987, erit. luvut 7-8; JeanLuc Nancy, La communauté désœuvrée. Christian Bourgois 1986, s. 16, 35-38; ks. myös Susanna Lindbergin hieno esitys, Filosofien ystäryys. Philippe Lacoue-Labarthe, Jean-Luc Nancy ja yhteisön kaksi mieltä. Tutkijaliitto 1997, erit. 55- 64.

66. Mt., s. 208-216. Tässä mielessä todellinen representoiva instanssi on Schmittin mukaan vain Rooman kirkko, tämä ainoa todellinen complexio oppositorum, sillä roomalaiskatolisuus perustuu representaatio-periaatteen tiukkaan toteuttamiseen. Se, mitä katolinen kirkko representoi, on tietenkin Jeesus Kristus, jonka idealle se antaa näkyvän muodon ja instituution. Ks. Schmitt, Roman Catholism, s. 8-12, 31-32.

67. Schmitt, Verfassungslehre, s. 247.

68. Mt.

69. Schmitt, Parlamentarismus, s. 37-38.

70. Mt., s. 37.

71. Mt., s. 41.

72. Ei kuitenkaan pidä luulla, että Schmitt olisi - kaikesta desisionismistaan huolimatta ollut vain suoran toiminnan mies, sillä hänen mukaansa inhimillisessä todellisuudessa kauneinta toimintaa, "ihmiselämän kriteeri", on nimenomaan puhe ja retoriikka. Kyse ei ole niinkään retorisesta keskustelusta tai väittelystä kuin representatiivisesta puheesta: "Se kyllä etenee [kuten väittely] antiteesien kautta, mutta nämä eivät ole ristirii- 
toja vaan complexioon muokattuja lukuisia ja monenkirjavia elementtejä, jotka antavat puheelle elävyyden." Schmitt, Roman Catholism, s. 22-23.

73. Schmitt, Parlamentarismus, s. 62; ks. myös Schmitt, Verfassungslehre, s. 466.

74. Edellä mainitussa diktatuurin historiaa kartoittavassa teoksessa Die Diktatur Schmitt erottaa toisistaan kaksi diktatuurin muotoa, komissaarisen ja suvereenin diktatuurin, joiden ero riippuu diktaattorin suhteesta olemassa olevaan konstituutioon. Komissaarisessa diktatuurissa diktaattorin tehtävänä on - poikkeusvaltuuksin varustettuna - puolustaa olemassa olevaa konstituutiota, kun taas suvereenin diktatuurin idea on vallankumouksellinen uuden konstituution ja uuden poliittisen järjestyksen aikaansaaminen. Proletariaatin - demokraattinen - diktatuuri on Schmittille nimenomaan suvereenia diktatuuria. Schmitt, Die Diktatur, s. 204-205.

75. Schmitt, Parlamentarismus, s. 66-67.

76. Mikhail Bakunin, Statism and Anarchy. Cambridge University Press 1990(1874), s. 135.

77. Mt. s. 134 .

78. Mt., s. $177-179$.

79. Mt., s. 46. Tätä samaa sanoi niin ikään Schmitt, mutta ei suinkaan Bakuninin tavoin toivoa täynnä vaan useimmiten surumielisen nos- talgian vallassa. Kansallissosialistien valtaannousun jälkeen hän kirjoittaa: "Valtiolla erityisenä järjestyksenä poliittisen yksikön sisällä - ei ole enää poliittisen monopolia. Se on vain yksi elin liikkeen [Bewegung] johtajan [Führer] palveluksessa." Carl Schmitt, Über die Drei Arten des rechtswissenschaftlichen Denkens. Hanseatische Verlagsanstalt 1934, s. 66. Eikä Hitlerin kuolema merkinnyt enää valtion uudestisyntymää, sillä kuten Schmitt (kirjansa Der Begriff des Politischen neljännen painoksen esipuheessa vuodelta 1963) painokkaasti korostaa, on valtio, tämä "poliittisen yksikön mallikuva, tämä hämmästyttävän monopolin - nimittäin poliittisen pätöksenteon monopolin - haltija, tämä eurooppalaisen muodon ja länsimaisen rationalismin mestariteos, syösty valtaistuimeltaan." Schmitt, Der Begriff des Politischen, s. 10.

80. Georges Sorel, "Apology for Violence". Teoksessa Reflections on Violence. Collier Books 1950(1908), s. 274.

81. Mt.

82. Georges Sorel, Reflections on Violence. Collier Books 1950(1908), s. 125.

83. Mt., s. 126.

84. Schmitt, Parlamentarismus, s. 88.

85. Mt., s. 89.

\section{K I R J A L LIS U U S}

Aristoteles, Politiikka. Suom. A.M. Anttila. Gaudeamus 1991.

Mikhail Bakunin, Statism and Anarchy. Cambridge University Press 1990(1874).

Juan Donoso Cortés, "Discorso sobre la dictatura" (1849). Teoksessa Obras Completas. Vol II. Editorial Católica 1970.

Philippe Lacoue-Labarthe, La fiction $d u$ politique. Christian Bourgois 1987.

Susanna Lindberg, Filosofien ystävyys. Philippe Lacoue-Labarthe, Jean-Luc Nancy ja yhteisön kaksi mieltä. Tutkijaliitto 1998.

Niccolo Machiavelli, Valtiollisia mietteitä. Suom. Kaarlo af Heurlin. WSOY 1998.

Joseph de Maistre, Considerations on France. Cambridge University Press 1994(1797).

Jean-Luc Nancy, La communauté désœuvrée. Christian Bourgois 1986.

Thomas Paine, Common Sense. Teoksessa Political Writings. Cambridge University Press 1989(1774).

Platon, Lait. Suom. Marja Itkonen-Kaila ja työryhmä. Otava 1986.

Samuel Pufendorf, Le Droit de la nature et des Gens. E \& J.R. Hourneisen 1732.

Jean-Jacques Rousseau, Yhteiskuntasopimuksesta. Suom. J.V. Lehtonen. Karisto 1988(1762).

Carl Schmitt, Die Diktatur. Von den Anfängen des modernen Souveränitätsgedankens bis zum proletarischen Klassenkampf. Duncker \& Humblot 1928(1921).

- Polittinen teologia. Neljä lukua suvereenisuusopista. Suom. Tapani Hietaniemi. Tutkijaliitto 1997(1922).

- Roman Catholism and Political Form. Greenwood Press 1996(1923).

- Die geistesgeschichtliche Lage des heutigen Parlamentarismus. Toinen painos. Duncker \& Humblot 1926(1923).

- Verfassungslehre. Duncker \& Humblot 1965(1928)

- "Wesen und Werden des faschistischen Staates" (1929). Teoksessa Positionen und Begriffe im Kampf mit Weimar, Genf, Ver- 
sailles. 1923-1939. Duncker \& Humblot 1985.

- Der Hüter der Verfassung. Duncker \& Humblot 1931.

- Legalität und Legitimität. Teoksessa Verfassungsrechtliche Aufsätze aus den Jahren 1924-1954. Materialien zu einer Verfassungslehre. Duncker \& Humblot 1958 (1932).

- Der Begriff des Politischen. Text von 1932 mit einem Vorwort unde drei Corollarien. Duncker \& Humblot 1979(1932).

— "Strong State and Sound Economy" (1932). Liite teoksessa Renato Cristi, Carl Schmitt and authoritarian liberalism. University of Wales Press 1998.

- "Weiterentwicklung des totalen Staats in Deutschland" (1933). Teoksessa Verfassungsrechtliche Aufsätze aus den Jahren 1924-1954. Materialien zu einer Ver- fassungslehre. Duncker \& Humblot 1958.

- Über die Drei Arten des rechtswissenschaftichen Denkens. Hanseatische Verlagsanstalt 1934.

- "Die Lage der europäischen Rechtwissenschaft" (1943/44). Teoksessa Verfassungsrechtliche Aufsätze aus den Jahren 19241954. Materialien zu einer Verfassungslehre. Duncker \& Humblot 1958.

- Donoso Cortés in gesamteuropäischer Interpretation - Vier Aufsätze. Greven Verlag 1950.

- Gespräch über die Macht und den Zugang zum Machtaber. Günther Neske 1954.

- Glossarium - Aufzeichnungen der Jahre 1947-1951. Duncker \& Humblot 1991.

Georges Sorel, Reflections on Violence. Collier Books 1950(1908).

Baruch Spinoza, Etiikka. Suom. Vesa Oittinen. Gaudeamus 1994(1677). 